Acta Universitatis Lodziensis

www.czasopisma.uni.lodz.pl/foe/

3(335) 2018

DOI: http://dx.doi.org/10.18778/0208-6018.335.07

\title{
Katarzyna Twarowska
}

Uniwersytet Marii Curie-Skłodowskiej w Lublinie, Wydział Ekonomiczny,

Katedra Gospodarki Światowej i Integracji Europejskiej, k.twarowska@umcs.pl

\section{Rola SDR w perspektywie zmian zasad funkcjonowania międzynarodowego systemu walutowego}

\begin{abstract}
Streszczenie: Rozwój dyskusji wskazującej na potrzebę podniesienia efektywności międzynarodowego systemu walutowego sprawia, że pojawia się wiele propozycji jego reformy. Z przedstawianych w literaturze koncepcji modyfikacji międzynarodowego systemu walutowego wyłaniają się dwa główne stanowiska: 1) przejście w kierunku systemu wielodewizowego oraz 2) stworzenie globalnego systemu walutowego przez oparcie go na Specjalnych Prawach Ciągnienia (SDR) lub wykreowanie ponadnarodowego pieniądza papierowego. Te okoliczności są przesłanką do podjęcia badań, których celem jest analiza wykorzystania SDR w funkcjach waluty międzynarodowej oraz ocena możliwości reformy międzynarodowego systemu walutowego, polegającej na zwiększeniu roli SDR. Z przeprowadzonych badań wynika, że przejęcie przez SDR funkcji waluty międzynarodowej jest możliwe, jednak wymaga istotnych zmian w polityce krajów oraz stworzenia warunków do szerszego zastosowania SDR, zarówno w sferze transakcji oficjalnych, jak i prywatnych. Zastosowane metody badawcze obejmują studium literatury przedmiotu oraz analizę danych statystycznych, głównie IMF i UNCTAD.
\end{abstract}

Słowa kluczowe: SDR, międzynarodowy system walutowy, waluta międzynarodowa, rezerwy walutowe, płynność międzynarodowa

JEL: F02, F31, F41, G15 


\section{Wprowadzenie}

Współczesny międzynarodowy system walutowy cechuje się wieloma sprzecznościami. Cały czas aktualny jest problem godzenia dwóch kwestii: zapewniania płynności międzynarodowej i zaufania rynków. Współczesny wymiar paradoksu Triffina polega na potrzebie kreowania deficytu płatniczego w USA dla zapewnienia płynności podtrzymującej wzrost gospodarki światowej, a to podważa zaufanie do dolara.

Ponadto kryzysy XXI wieku, w tym przede wszystkim kryzys finansowo-gospodarczy 2008-2009, który rozpoczął się na amerykańskim rynku nieruchomości, a następnie kryzys zadłużeniowy w strefie euro, podważyły zaufanie do głównych walut - dolara i euro - jako jednostek pełniących funkcję pieniądza międzynarodowego, a w szczególności jako środka tezauryzacji. W tym kontekście zasadne wydaje się stworzenie nowej międzynarodowej jednostki rezerwowej bądź też nadanie takiego statusu już istniejącej jednostce Międzynarodowego Funduszu Walutowego (IMF) - Specjalnym Prawom Ciągnienia (SDR).

Wyżej opisane przesłanki zachęcają do podjęcia badań, których celem jest analiza i ocena SDR w pełnieniu funkcji waluty międzynarodowej oraz ocena możliwości zwiększenia roli SDR w przyszłości w kontekście propozycji reform międzynarodowego systemu walutowego (MSW), a także wskazanie korzyści i zagrożeń związanych z oparciem MSW na SDR. Autorka podejmuje próbę weryfikacji hipotezy mówiącej, że wzrost roli SDR w pełnieniu funkcji waluty międzynarodowej umożliwiłby reformę międzynarodowego systemu walutowego zwiększającą jego stabilność. Podstawowe metody badawcze wykorzystane w pracy to studia literatury przedmiotu oraz analiza danych statystycznych (m.in. IMF i UNCTAD). Badania obejmują okres od lat siedemdziesiątych XX wieku do 2016 roku, a w przypadku niektórych danych od połowy lat dziewięćdziesiątych.

\section{SDR a problem płynności międzynarodowej - wprowadzenie teoretyczne}

Rozwój handlu międzynarodowego oraz rynków finansowych po drugiej wojnie światowej, a także rosnące zapotrzebowanie na rezerwy walutowe generowały popyt na walutę międzynarodową (Obstfeld, 2011: 3), której funkcje w warunkach systemu z Bretton Woods pełnił dolar amerykański. Zobowiązanie krajów do utrzymywania stałych kursów walutowych powodowało konieczność interwencji w USD na krajowych rynkach walutowych, a dzięki pełnieniu funkcji waluty interwencyjnej dolar stał się głównym źródłem płynności międzynarodowej oraz głównym aktywem rezerwowym w MSW (Bogołębska, 2013: 245). Aby jednak 
zapewniać gospodarce światowej płynność, konieczny był deficyt bilansu płatniczego Stanów Zjednoczonych. Zjawisko to zauważył i opisał w latach sześćdziesiątych XX wieku Robert Triffin (Smaghi, 2011). Dylemat Triffina reprezentuje „podażową stronę" wizji płynności międzynarodowej. Alternatywne wizje płynności międzynarodowej prezentowali między innymi H.G. Johnson (1964), Ch.P. Kindleberger (1965) i R.I. McKinnon (1969), według których deficyt płatniczy USA powinien być nie determinantą, a wynikiem określanym przez skłonność do akumulacji rezerw przez resztę świata (Bogołębska, 2013: 245).

Rosnący deficyt bilansu płatniczego USA w latach sześćdziesiątych XX wieku był źródłem spadku zaufania do dolara, ponieważ coraz większa ilość tej waluty w obiegu podważała możliwość pokrycia dolarów w złocie przy stałym parytecie 35 USD za uncję trojańską złota. Stopień pokrycia rezerw dolarowych zasobami złota systematycznie spadał, w latach 1949-1965 średniorocznie o $12,6 \%$ - z poziomu 7,14 do 0,95. Od momentu, gdy wymienialne aktywa dolarowe w portfelach zagranicznych banków centralnych przekroczyły całkowitą wartość zasobów złota w USA, wymienialność według oficjalnych parytetów stała się zależna od chęci krajów do utrzymywania niezmienionej kompozycji rezerw (Bogołębska, 2013: 246).

Wobec tego problemu, aby zapobiec kryzysowi międzynarodowego systemu walutowego, Międzynarodowy Fundusz Walutowy podjął w 1969 roku działania polegające na wprowadzeniu nowej jednostki monetarnej służącej uzupełnieniu płynności międzynarodowej - Specjalnych Praw Ciągnienia (Special Drawing Rights - SDR) (Clark, Polak, 2004: 51-57).

Kreacja SDR odbywała się przez alokacje (generalne lub nadzwyczajne). Jednak M. Obstfeld (2011: 1) podkreśla, że alokacja SDR nie tworzy dodatkowej płynności międzynarodowej, ponieważ nie dochodzi do kreacji pieniądza, a jedynie do zwiększenia siły nabywczej danego kraju przez mechanizm kredytowy. Formalnie jednak SDR zaliczane są do oficjalnej płynności międzynarodowej (Skopiec, 2015: 93).

B. Eichengreen i J.A. Frankel (1996: 2) uważają, że nie ma istotnych argumentów potwierdzających, że alokacja SDR eliminuje niedobory płynności międzynarodowej oraz wewnętrzną niestabilność procesu kreowania rezerw. Podkreślają jednocześnie, że SDR dostarczają środków potrzebnych do walki z kryzysami finansowymi, chociaż istnieją bardziej bezpośrednie i skuteczniejsze instrumenty. Podobnego zdania był J. Schroder (1990: 70), który zauważył, że mobilność kapitału zredukowała popyt na rezerwy walutowe, eliminując przesłanki dla istnienia SDR. Wraz z przyspieszeniem procesów globalizacji gospodarki światowej, jak również występowaniem kryzysów walutowych spowodowanych nagłym odpływem kapitału, coraz większe znaczenie zyskiwał przezornościowy popyt na rezerwy walutowe (Aizenman, Lee, 2006), co skutkowało wzrostem akumulacji rezerw głównie przez kraje rozwijające się (Bogołębska, 2011). W strukturze przedmio- 
towej rezerw krajów rozwijających się dominuje przede wszystkim dolar, jednak w warunkach zwiększenia roli Międzynarodowego Funduszu Walutowego dolar w tej funkcji mógłby być zastępowany przez SDR.

\section{Geneza i charakterystyka SDR jako środka zapewniania płynności międzynarodowej}

Pomysł stworzenia Specjalnych Praw Ciągnienia pojawił się na początku lat sześćdziesiątych XX wieku (Wilkie, 2012: 15), jednak ich pierwsza emisja odbyła się w 1970 roku$^{1}$. Celem emisji SDR było uzupełnienie oficjalnych rezerw krajów członkowskich. Na podstawie postanowień statutu IMF może przyznawać SDR państwom członkowskim proporcjonalnie do ich udziałów wniesionych do kapitału zakładowego funduszu (Bird, 2003: 73). Akt założycielski określa ponadto okoliczności, w których może dojść do emisji SDR. Zgodnie z postanowieniami tego dokumentu alokacja może być dokonana tylko wówczas, gdy istnieje globalna długookresowa potrzeba uzupełnienia światowych rezerw walutowych, a celem emisji jest zwiększenie płynności na międzynarodowym rynku finansowym (Proczek, 2016: 122).

Pierwsza emisja SDR miała miejsce w latach 1970-1972 w trzech transzach o łącznej wartości 9,5 mld SDR. Początkowo SDR miały wyznaczony parytet w złocie, równy parytetowi dolara amerykańskiego i wartość jednostki SDR wynosiła $0,88671 \mathrm{~g}$ złota. Stąd w literaturze nazwano SDR papierowym złotem (Boughton, 2001: 924). Upłynnienie kursów walutowych w 1973 roku przez większość krajów należących do systemu z Bretton Woods spowodowało zmianę sposobu wyznaczania wartości SDR i od lipca 1974 roku do grudnia 1980 roku była ona oparta na koszyku 16 walut krajów będących największymi eksporterami. Od tego czasu udziały poszczególnych walut w koszyku SDR miały być weryfikowane co pięć lat, aby jak najlepiej oddawać realia międzynarodowych rynków finansowych. Upadek systemu walutowego z Bretton Woods i wdrożenie postanowień konferencji w Kingston (Mucha-Leszko, Twarowska, 2016: 51) wiązały się z koniecznością wprowadzenia drugiej poprawki do aktu założycielskiego IMF, która znosiła oficjalną cenę złota, a za główny środek płatniczy uznała SDR (Proczek, 2016: 121).

Druga emisja odbyła się w latach 1979-1981 również w trzech transzach, tym razem o łącznej wartości 12,1 mld SDR. Przyczyną emisji był ponownie spadek zaufania do dolara amerykańskiego i potrzeba uzupełnienia płynności międzynarodowej (Boughton, 2001: 924). W 1981 roku miała miejsce ponadto zmiana

${ }^{1}$ Emisja SDR wymagała wprowadzenia pierwszej poprawki do IMF's Articles of Agreement z 1969 roku. Poprawka weszła w życie 1 stycznia 1970 roku (za: Wilkie, 2012). 
sposobu wyznaczania wartości SDR, a liczba walut w koszyku została zredukowana do pięciu: dolar amerykański, marka niemiecka, frank francuski, funt brytyjski i jen japoński. Kolejna modyfikacja koszyka SDR wynikała z zastąpienia przez walutę euro w 1999 roku 11 walut narodowych, z których dwie znajdowały się wcześniej w koszyku SDR (marka niemiecka i frank francuski). Udziały poszczególnych walut w koszyku SDR po wprowadzeniu euro zostały zaprezentowane w tabeli 1.

Tabela 1. Struktura walutowa koszyka SDR w latach 1999-2016 (w \%)

\begin{tabular}{|l|c|c|c|c|c|}
\hline \multicolumn{1}{|c|}{ Waluta } & 1999-2000 & 2001-2005 & 2006-2010 & $\begin{array}{c}\text { 2011 - } \\
\text { wrzesień 2016 }\end{array}$ & $\begin{array}{c}\text { Od października } \\
\mathbf{2 0 1 6}\end{array}$ \\
\hline $\begin{array}{l}\text { Dolar amerykański } \\
\text { (USD) }\end{array}$ & 39 & 44 & 44 & 41,9 & 41,73 \\
\hline Euro (EUR) & 32 & 31 & 34 & 37,4 & 30,93 \\
\hline Jen japoński (JPY) & 18 & 14 & 11 & 9,4 & 8,33 \\
\hline $\begin{array}{l}\text { Funt szterling } \\
\text { (GBP) }\end{array}$ & 11 & 11 & 11 & 11,3 & 8,09 \\
\hline $\begin{array}{l}\text { Chiński renminbi } \\
\text { (CNY) }\end{array}$ & - & - & - & - & 10,92 \\
\hline
\end{tabular}

Źródło: opracowanie własne na podstawie: IMF, 2010b: 5, 18; IMF, 2016: 15

W 1996 roku została zgłoszona propozycja specjalnej alokacji, umożliwiająca przyznawanie SDR również krajom, które przystąpiły do IMF już po dokonaniu drugiej emisji, czyli przede wszystkim krajom Europy Środkowo-Wschodniej i byłym republikom radzieckim. Do przeprowadzenia tej alokacji potrzebna była zmiana statutu IMF wymagająca ratyfikacji przez parlamenty krajów członkowskich. Stany Zjednoczone, kierując się dążeniem do utrzymania roli dolara jako dominującej waluty międzynarodowej, skorzystały z faktu dysponowania $16,74 \%$ głosów na forum IMF, gwarantującego im prawo weta i wstrzymały się z ratyfikacją poprawki. Dopiero globalny kryzys finansowo-gospodarczy i związane z nim problemy w funkcjonowaniu MSW przyczyniły się do zmiany stanowiska USA. W efekcie ratyfikacji czwartej poprawki do statutu IMF SDR zostały wyemitowane po raz trzeci we wrześniu 2009 roku (204,1 mld SDR) (Jurek, 2011: 345-346). Z tej puli 21,4 mld SDR zostało przekazane 40 krajom, które przystąpiły do IMF po 1982 roku.

Rosnące znaczenie krajów rozwijających się (a przede wszystkim wysoki udział Chin w światowym handlu) stało się przyczyną kolejnej modyfikacji składu koszyka SDR, polegającej na włączeniu renminbi od października 2016 roku. Skład koszyka SDR został ustalony zgodnie z wcześniejszą praktyką na 5 lat i kolejny przegląd powinien odbyć się do 30 września 2021 roku. Aby waluta mogła zostać włączona do koszyka SDR, muszą być spełnione dwa podstawowe warunki: po pierwsze, kraj emitujący daną walutę musi być znaczącym eksporterem, 
a po drugie, kurs waluty musi być ustalany rynkowo. Spełnienie pierwszego kryterium nie budzi wątpliwości, ponieważ Chiny są największym eksporterem towarów na świecie i w 2015 roku wyprzedzały USA oraz Niemcy, posiadając 13,3\% udziału w światowym eksporcie towarów (udział USA wynosił 9,4\%) oraz 11,6\% udziału w eksporcie towarów i usług łącznie (udział USA 10,6\%) (UNCTAD, 2017). Większym problemem było spełnienie drugiego kryterium, ponieważ Chiny przez lata realizowały strategię utrzymywania zaniżonej wartości renminbi, aby wspierać krajowych eksporterów (Liberska, 2010: 339). W celu włączenia chińskiej waluty do koszyka SDR podjęto szereg działań, między innymi rozszerzono dzienną marżę wahań renminbi względem kursu referencyjnego z $1 \%$ do $2 \%$ oraz wprowadzono ułatwienia w rozliczaniu transakcji denominowanych w walucie chińskiej (Neely, 2017). W planach są dalsze działania w kierunku liberalizacji systemu finansowego Chin, o czym świadczy zapowiedź wprowadzenia w życie do 2020 roku ustawy, która umożliwi pełną wymienialność chińskiej waluty oraz otwarcie rynku kapitałowego i finansowego (Bloomberg, 2015).

\section{Ocena wykorzystania SDR w pełnieniu funkcji pieniądza międzynarodowego}

\subsection{Funkcje waluty międzynarodowej}

Waluta międzynarodowa jest to jednostka monetarna lub waluta narodowa pełniąca trzy klasyczne funkcje pieniądza dla nierezydentów, zarówno w sferze oficjalnej, jak i prywatnej: 1) środka tezauryzacji, 2) środka płatniczego oraz 3) jednostki rozliczeniowej (por. tab. 2).

Tabela 2. Funkcje pieniądza międzynarodowego

\begin{tabular}{|l|l|l|}
\hline \multicolumn{1}{|c|}{ Funkcje pieniądza } & \multicolumn{1}{c|}{ Sektor prywatny } & \multicolumn{1}{c|}{ Sektor publiczny } \\
\hline Środek tezauryzacji & Waluta inwestycyjna & Waluta rezerwowa \\
\hline Środek płatniczy & $\begin{array}{l}\text { Waluta transakcji w handlu } \\
\text { międzynarodowym i w wy- } \\
\text { mianie walut }\end{array}$ & Waluta interwencyjna \\
\hline Jednostka rozliczeniowa & $\begin{array}{l}\text { Waluta fakturowania i noto- } \\
\text { wania cen }\end{array}$ & $\begin{array}{l}\text { Waluta odniesienia dla kursów } \\
\text { walutowych (waluta referen- } \\
\text { cyjna) }\end{array}$ \\
\hline
\end{tabular}

Źródło: Kenen, 1983: 16

Choć Specjalne Prawa Ciągnienia określane są mianem substytutu pieniądza międzynarodowego, to w praktyce ich wykorzystanie w pełnieniu funkcji waluty międzynarodowej jest mocno ograniczone. S. Aiyar (2009: 1) twierdzi, że pełnią 
one obecnie dwie funkcje: jednostki obrachunkowej IMF oraz linii kredytowej między członkami funduszu, czyli służą pozyskiwaniu walut swobodnie używanych od innych krajów członkowskich IMF, głównie w celu pozyskania środków do spłaty zobowiązań płatniczych wobec zagranicy przez kraje notujące deficyty bilansu obrotów bieżących (Skopiec, 2015: 92). Ta własność determinuje wykorzystanie SDR również w pełnieniu innych funkcji waluty międzynarodowej.

Powszechne wykorzystanie SDR we wszystkich funkcjach waluty międzynarodowej z przyczyn formalnych nie jest możliwe i wymagałoby zmiany przepisów. Statut IMF ogranicza stosowanie SDR jedynie do sfery oficjalnej, co uniemożliwia użycie ich w sferze prywatnej i hamuje rozwój rynków dla SDR, a także aktywów nominowanych w tej jednostce. W sferze prywatnej SDR nie pełnią zatem funkcji jednostki rozliczeniowej i środka płatniczego, ponieważ nie mogą być wykorzystywane do fakturowania i rozliczania handlu międzynarodowego, jak również do dokonywania transakcji finansowych. Ponadto nie pełnią w sferze prywatnej funkcji środka tezauryzacji, gdyż nie jest możliwe inwestowanie w instrumenty nominowane w SDR (Skopiec, 2015: 97).

\subsection{Wykorzystanie SDR w funkcji waluty referencyjnej}

We współczesnym międzynarodowym systemie walutowym kraje posiadają swobodę wyboru stosowanego reżimu kursowego. Zgodnie z postanowieniem IMF kraje, które wybrały jedną z form kursu stałego lub kierowanego, mogą odnosić wartość swojej waluty do SDR, innej jednostki stanowiącej koszyk walut lub waluty innego kraju czy unii walutowej.

Ponadto SDR posiadają własności pożądane z punktu widzenia realizacji funkcji waluty referencyjnej, gdyż przyjęty sposób określania kursu SDR sprawia, że są one jednostką o bardzo stabilnej wartości (por. tab. 3).

Tabela 3. Zmienność kursu SDR

\begin{tabular}{|l|c|c|c|}
\hline & $\begin{array}{c}\text { Kurs SDR w stosunku } \\
\text { do USD (od 3 stycznia } \\
\text { 1984 do 31 marca } \\
\mathbf{2 0 1 7} \text { roku) }\end{array}$ & $\begin{array}{c}\text { Kurs SDR w stosunku } \\
\text { do USD (XDRUSD; } \\
\text { od 2 stycznia } \\
\text { 1991 do 30 marca } \\
\text { 2017 roku) }\end{array}$ & $\begin{array}{c}\text { Kurs USDEUR } \\
\text { (od 2 stycznia } \\
\text { 1991 do 30 marca } \\
\mathbf{2 0 1 7} \text { roku) }\end{array}$ \\
\hline Średni kurs & 1,3932 & 1,4423 & 0,8431 \\
\hline Wariancja & 0,0192 & 0,0082 & 0,0132 \\
\hline $\begin{array}{l}\text { Odchylenie } \\
\text { standardowe }\end{array}$ & 0,1385 & 0,0903 & 0,1152 \\
\hline
\end{tabular}

Źródło: opracowanie własne na podstawie: Stooq, 2017 
Jednak w praktyce SDR były wybierane przez kraje jako waluta zaczepu dość rzadko (tab. 4), a obecnie żaden kraj członkowski IMF nie stosuje SDR jako jednostki odniesienia w swoim systemie kursowym. Wynika to z faktu, iż większość krajów stosuje kursy płynne, a te, które wprowadzają w swoich reżimach kursowych powiązanie z określoną jednostką referencyjną, w przeważającej mierze wybierają dolara amerykańskiego lub euro (Bilski, 2006: 243-245).

Tabela 4. Wykorzystanie walut w funkcji waluty referencyjnej (zaczepu)

\begin{tabular}{|c|c|c|c|c|c|c|c|c|c|c|c|c|}
\hline \multirow{3}{*}{$\begin{array}{c}\text { Liczba krajów } \\
\text { (odsetek krajów } \\
\text { w\%) }\end{array}$} & \multicolumn{12}{|c|}{ Lata } \\
\hline & \multicolumn{2}{|c|}{1976} & \multicolumn{2}{|c|}{1983} & \multicolumn{2}{|c|}{1990} & \multicolumn{2}{|c|}{1998} & \multicolumn{2}{|c|}{2013} & \multicolumn{2}{|c|}{2015} \\
\hline & L. & $\%$ & L. & $\%$ & L. & $\%$ & L. & $\%$ & L. & $\%$ & L. & $\%$ \\
\hline \multicolumn{13}{|l|}{$\begin{array}{l}\text { Systemy kursu sta- } \\
\text { łego, kurs centralny } \\
\text { określony wobec: }\end{array}$} \\
\hline SDR & 12 & 9,4 & 15 & 10,3 & 6 & 4,0 & 4 & 2,2 & 0 & 0,0 & 0 & 0,0 \\
\hline $\begin{array}{l}\text { Dolara } \\
\text { amerykańskiego }\end{array}$ & 54 & 42,2 & 38 & 26,2 & 30 & 19,9 & 24 & 13,1 & 44 & 23,0 & 42 & 22,0 \\
\hline Franka francuskiego & 13 & 10,2 & 13 & 9,0 & 14 & 9,3 & 15 & 8,2 & 0 & 0,0 & 0 & 0,0 \\
\hline Euro & 0 & 0,0 & 0 & 0,0 & 0 & 0,0 & 0 & 0,0 & 27 & 14,1 & 25 & 13,1 \\
\hline $\begin{array}{l}\text { Innej jednostki } \\
\text { pieniężnej }\end{array}$ & 7 & 5,4 & 5 & 3,4 & 5 & 3,3 & 12 & 6,6 & 8 & 4,2 & 8 & 4,2 \\
\hline $\begin{array}{l}\text { Innego koszyka } \\
\text { walut }\end{array}$ & 7 & 5,5 & 23 & 15,9 & 33 & 21,9 & 27 & 14,8 & 13 & 6,8 & 12 & 6,3 \\
\hline $\begin{array}{l}\text { Systemy kursu płyn- } \\
\text { nego (kraje stosują- } \\
\text { ce bezpośredni cel } \\
\text { inflacyjny, cel w po- } \\
\text { staci kontroli podaży } \\
\text { pieniądza i inne) }\end{array}$ & 35 & 27,3 & 51 & 35,2 & 63 & 41,6 & 101 & 55,1 & 99 & 51,8 & 104 & 54,5 \\
\hline Razem & 128 & 100 & 145 & 100 & 151 & 100 & 183 & 100 & 191 & 100 & 191 & 100 \\
\hline
\end{tabular}

Źródło: Twarowska, 2016a

\subsection{Wykorzystanie SDR jako składnika oficjalnych aktywów rezerwowych}

Analizując SDR jako składnik oficjalnych aktywów rezerwowych, koniecznie należy wspomnieć o bezprecedensowym zjawisku akumulacji rezerw od połowy lat dziewięćdziesiątych XX wieku (rys. 1). Wartość globalnych rezerw walutowych wzrosła z poziomu 1,4 bln USD (4,5\% PKB) w 1995 roku do 11 bln USD (14,6\%) w 2016 roku (COFER, 2017). Zjawisko to wywołane było serią kryzysów walutowych, głównie w krajach azjatyckich, w związku z czym kraje, kierując się motywem ostrożnościowym, chciały zapewnić sobie wystarczające zasoby pie- 
niądza międzynarodowego jako bufor bezpieczeństwa na wypadek zagrożeń dla stabilności waluty. Charakterystyczną cechą akumulacji rezerw walutowych jest ponadto fakt, iż jest ona generowana głównie przez kraje rozwijające się i rynki wschodzące (por. Nakonieczna-Kisiel, 2013).

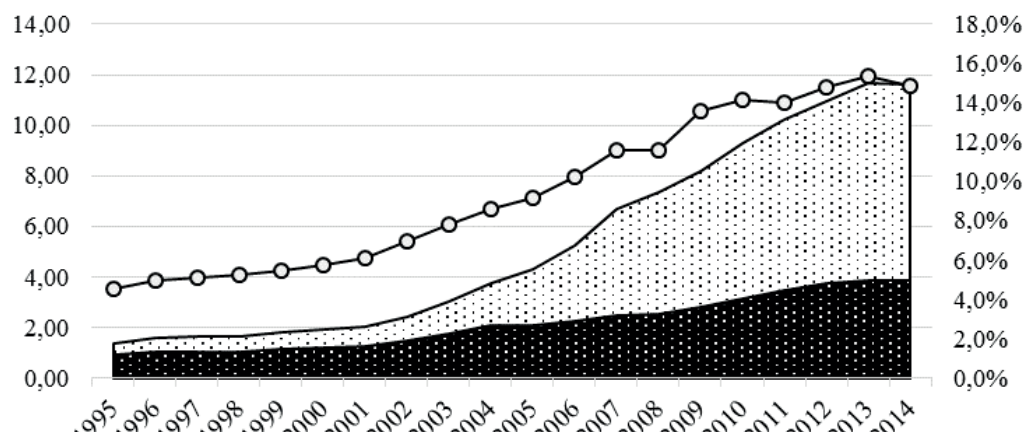

$\because$ Rynki wschodzące i kraje rozwijające się

-:-2.:Kraje wysoko rozwinięte

$\multimap-$ Rezerwy walutowe jako procent światowego PKB

Rysunek 1. Wartość światowych rezerw walutowych (w bln USD i \% PKB)

Źródło: opracowanie własne na podstawie: COFER, 2017; IMF, 2017a

Dominującą walutą międzynarodową w oficjalnych rezerwach pozostawał dolar amerykański, który posiadał ponadtrzykrotną przewagę nad kolejną walutą - euro (tab. 5).

Tabela 5. Struktura walutowa oficjalnych rezerw walutowych (w \%)

\begin{tabular}{|l|c|c|c|c|c|c|c|c|c|c|c|c|c|}
\cline { 2 - 13 } \multicolumn{1}{c|}{} & $\mathbf{1 9 9 5}$ & $\mathbf{1 9 9 8}$ & $\mathbf{1 9 9 9}$ & $\mathbf{2 0 0 1}$ & $\mathbf{2 0 0 3}$ & $\mathbf{2 0 0 5}$ & $\mathbf{2 0 0 7}$ & $\mathbf{2 0 0 9}$ & $\mathbf{2 0 1 1}$ & $\mathbf{2 0 1 3}$ & $\mathbf{2 0 1 4}$ & $\mathbf{2 0 1 5}$ & $\mathbf{2 0 1 6}$ \\
\hline $\begin{array}{l}\text { Dolar amery- } \\
\text { kański (USD) }\end{array}$ & 59,0 & 69,3 & 71,0 & 71,5 & 65,4 & 66,5 & 63,9 & 62,1 & 62,6 & 61,2 & 63,3 & 64,2 & 63,3 \\
\hline Euro (EUR) & - & - & 17,9 & 19,2 & 25,0 & 23,9 & 26,1 & 27,7 & 24,4 & 24,2 & 21,9 & 19,7 & 20,3 \\
\hline $\begin{array}{l}\text { Funt szterling } \\
\text { (GBP) }\end{array}$ & 2,1 & 2,7 & 2,9 & 2,7 & 2,9 & 3,7 & 4,8 & 4,2 & 3,8 & 4,0 & 3,8 & 4,9 & 4,5 \\
\hline $\begin{array}{l}\text { Jen japoński } \\
\text { (JPY) }\end{array}$ & 6,8 & 6,2 & 6,4 & 5,0 & 4,4 & 4,0 & 3,2 & 2,9 & 3,6 & 3,8 & 3,9 & 4,0 & 4,5 \\
\hline $\begin{array}{l}\text { Dolar kanadyj- } \\
\text { ski (CAD) }\end{array}$ & - & - & - & - & - & - & - & - & - & 1,8 & 1,9 & 1,9 & 2,0 \\
\hline $\begin{array}{l}\text { Dolar australij- } \\
\text { ski (AUD) }\end{array}$ & - & - & - & - & - & - & - & - & - & 1,8 & 1,8 & 1,9 & 1,9 \\
\hline $\begin{array}{l}\text { Frank szwaj- } \\
\text { carski (CHF) }\end{array}$ & 0,3 & 0,3 & 0,2 & 0,2 & 0,2 & 0,1 & 0,2 & 0,1 & 0,1 & 0,3 & 0,3 & 0,3 & 0,2 \\
\hline $\begin{array}{l}\text { Marka nie- } \\
\text { miecka (DEM) }\end{array}$ & 15,8 & 13,8 & - & - & - & - & - & - & - & - & - & - & - \\
\hline
\end{tabular}




\begin{tabular}{|l|r|c|c|c|c|c|c|c|c|c|c|c|c|}
\cline { 2 - 14 } \multicolumn{1}{c|}{} & $\mathbf{1 9 9 5}$ & $\mathbf{1 9 9 8}$ & $\mathbf{1 9 9 9}$ & $\mathbf{2 0 0 1}$ & $\mathbf{2 0 0 3}$ & $\mathbf{2 0 0 5}$ & $\mathbf{2 0 0 7}$ & $\mathbf{2 0 0 9}$ & $\mathbf{2 0 1 1}$ & $\mathbf{2 0 1 3}$ & $\mathbf{2 0 1 4}$ & $\mathbf{2 0 1 5}$ & $\mathbf{2 0 1 6}$ \\
\hline ECU & 8,5 & 1,3 & - & - & - & - & - & - & - & - & - & - & - \\
\hline $\begin{array}{l}\text { Frank francu- } \\
\text { ski (FRF) }\end{array}$ & 2,4 & 1,6 & - & - & - & - & - & - & - & - & - & - & - \\
\hline $\begin{array}{l}\text { Gulden holen- } \\
\text { derski (NLG) }\end{array}$ & 0,3 & 0,3 & - & - & - & - & - & - & - & - & - & - & - \\
\hline Inne waluty & 4,9 & 4,5 & 1,6 & 1,3 & 2,0 & 1,7 & 1,8 & 3,0 & 5,5 & 2,8 & 3,1 & 3,1 & 3,3 \\
\hline
\end{tabular}

Źródło: opracowanie własne na podstawie: COFER, 2017

Rola SDR jako składnika oficjalnych rezerw walutowych pozostawała niewielka. W strukturze rezerw dominowały aktywa nominowane w walutach wymienialnych (wzrost udziału z 49,5\% w 1984 roku do 88,67\% w 2015 roku). Drugą pod względem wartości kategorią aktywów rezerwowych jest złoto, choć jego udział spadł z 42,25\% w 1984 roku do 8,57\% w 2015 roku (tab. 6 i rys. 2). Od lat osiemdziesiątych XX wieku następuje odbudowa roli złota w funkcji aktywu rezerwowego oraz prywatyzacja złota i powrót banków centralnych na prywatny rynek złota (Bilski, 2015: 9). Natomiast udział SDR w całym analizowanym okresie nie przekroczył 3,5\% i wynosił w 1984 roku 2,34\%, następnie systematycznie spadał do 0,36\% w 2008 roku, a w wyniku alokacji dokonanej w 2009 roku, która skokowo zwiększyła globalny zasób SDR, udział Specjalnych Praw Ciągnienia w strukturze rezerw walutowych wzrósł do $3,31 \%$.

Tabela 6. Struktura oficjalnych aktywów rezerwowych krajów członkowskich IMF (w mld SDR i w \%)

\begin{tabular}{|l|r|r|r|r|r|r|r|r|r|r|}
\hline & $\mathbf{1 9 8 4}$ & $\mathbf{1 9 9 0}$ & $\mathbf{1 9 9 5}$ & $\mathbf{2 0 0 0}$ & $\mathbf{2 0 0 5}$ & $\mathbf{2 0 0 8}$ & $\mathbf{2 0 0 9}$ & $\mathbf{2 0 1 3}$ & $\mathbf{2 0 1 5}$ \\
\hline \multicolumn{8}{|c|}{ W mld SDR } \\
\hline $\begin{array}{l}\text { Transza rezerwo- } \\
\text { wa w IMF }\end{array}$ & 41,6 & 23,7 & 36,7 & 47,4 & 28,6 & 25,1 & 38,7 & 97,5 & 68,4 \\
\hline SDR & 16,5 & 20,4 & 19,8 & 18,5 & 20,1 & 18,9 & 200,8 & 191 & 189,5 \\
\hline $\begin{array}{l}\text { Aktywa w walu- } \\
\text { tach wymienial- } \\
\text { nych }\end{array}$ & 348,9 & 593,8 & 931,8 & 1490,2 & 3022,6 & 4763,9 & 5208,2 & 7586,2 & 8292,4 \\
\hline Złoto & 297,8 & 254,1 & 235,8 & 200,6 & 315,5 & 481,6 & 609,9 & 721,5 & 801,7 \\
\hline $\begin{array}{l}\text { Rezerwy łącznie } \\
\text { (wraz ze złotem) }\end{array}$ & 704,8 & 892 & 1224 & 1756,6 & 3386,8 & 5289,8 & 6057,5 & 8596,4 & 9352,3 \\
\hline & & & & & & & & & & \\
\hline $\begin{array}{l}\text { Transza rezerwo- } \\
\text { wa w IMF }\end{array}$ & 5,90 & 2,66 & 3,00 & 2,70 & 0,84 & 0,47 & 0,64 & 1,13 & 0,73 \\
\hline SDR & 2,34 & 2,29 & 1,62 & 1,05 & 0,59 & 0,36 & 3,31 & 2,22 & 2,03 \\
\hline $\begin{array}{l}\text { Aktywa w walu- } \\
\text { tach wymienial- } \\
\text { nych }\end{array}$ & 49,50 & 66,57 & 76,13 & 84,83 & 89,25 & 90,06 & 85,98 & 88,25 & 88,67 \\
\hline Złoto & 42,25 & 28,49 & 19,26 & 11,42 & 9,32 & 9,10 & 10,07 & 8,39 & 8,57 \\
\hline
\end{tabular}

Źródło: opracowanie własne na podstawie: lata 1984-1989: IMF, 1990: 66; 1990-1993: IMF, 1996: 162; 1994-1999: IMF, 2000: 110; 2000-2004: IMF, 2005: 108; 2005-2008: IMF, 2010a: 3; 2009-2015 marzec: IMF, 2015: 3 

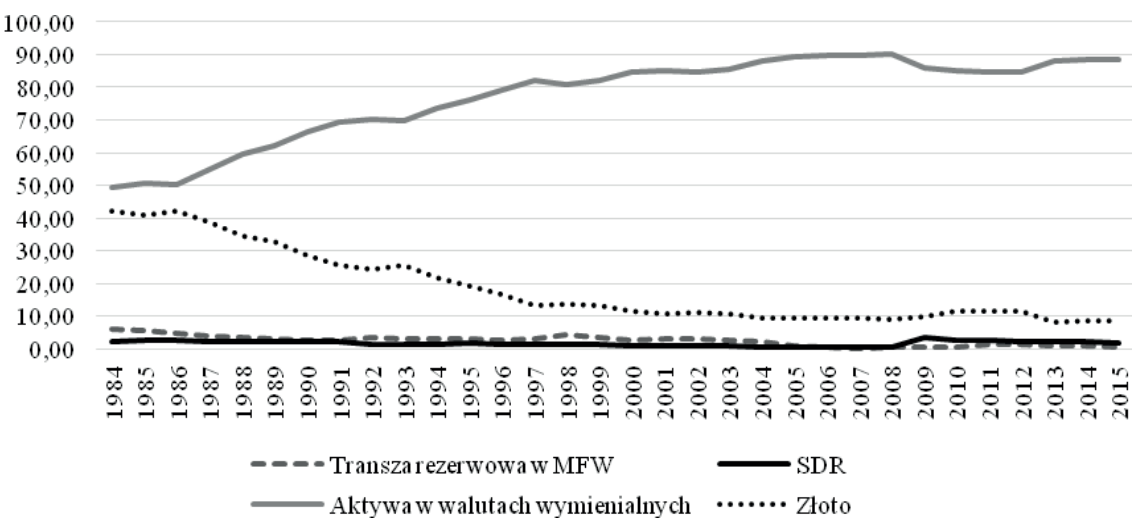

Rysunek 2. Struktura oficjalnych aktywów rezerwowych krajów członkowskich IMF (w \%)

Źródło: opracowanie własne na podstawie: lata 1984-1989: IMF, 1990: 66; 1990-1993: IMF, 1996: 162; 1994-1999: IMF, 2000: 110; 2000-2004: IMF 2005: 108; 2005-2008: IMF 2010a: 3; 2009-2015 marzec: IMF, 2015: 3

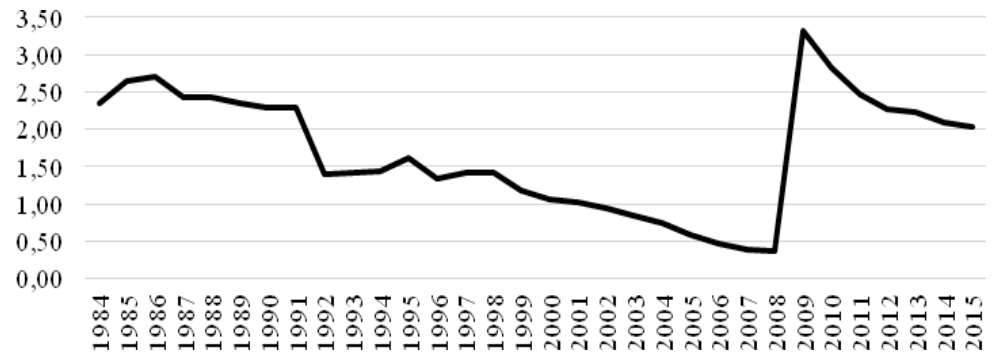

Rysunek 3. Udział SDR w oficjalnych aktywach rezerwowych krajów członkowskich IMF (w \%) Źródło: opracowanie własne na podstawie: lata 1984-1989: IMF, 1990: 66; 1990-1993: IMF, 1996: 162; 1994-1999: IMF, 2000: 110; 2000-2004: IMF, 2005: 108; 2005-2008: IMF, 2010a: 3; 2009-2015 marzec: IMF, 2015: 3

Warto zwrócić uwagę na różnice występujące w akumulacji rezerw walutowych w formie SDR przez kraje wysoko rozwinięte i rozwijające się. Udział krajów rozwijających się i rynków wschodzących w globalnej akumulacji rezerw w analizowanym okresie wzrastał i wynosił w 2014 roku 67\% (COFER, 2017), z kolei udział SDR będących w posiadaniu tej grupy krajów w 2014 roku stanowił zaledwie 33,9\% wszystkich wyemitowanych jednostek (rys. 5). SDR są marginalnym składnikiem rezerw walutowych w krajach rozwijających się, w strukturze rezerw posiadanych przez te kraje SDR stanowiły w 2015 roku 1,1\%, ale przed ostatnią alokacja ich udział wynosił w 2008 roku zaledwie 0,1\% (rys. 4).

W 1984 roku kraje wysoko rozwinięte posiadały aż 81,2\% wyemitowanych SDR, natomiast kraje wschodzące i rozwijające się zaledwie 18,8\%. Wskutek przeprowadzonej w 2009 roku alokacji, w której uczestniczyły również kraje niżej rozwinięte, dysproporcja ta uległa pewnemu zmniejszeniu, jednak w dalszym ciągu większość wyemitowanych SDR przypada na kraje wysoko rozwinięte $(66,1 \%$ w 2015 roku). Można zatem stwierdzić, że struktura geograficzna rezerw przecho- 
wywanych w SDR jest pochodną udziału krajów w alokacji SDR, gdzie dominują Stany Zjednoczone (17,46\%), na drugiej pozycji jest Japonia $(6,48 \%)$, a trzecie miejsce uzyskały Chiny $(6,41 \%)$, które od kilkunastu lat dynamicznie zwiększają zasoby oficjalnych rezerw walutowych (tab. 7).

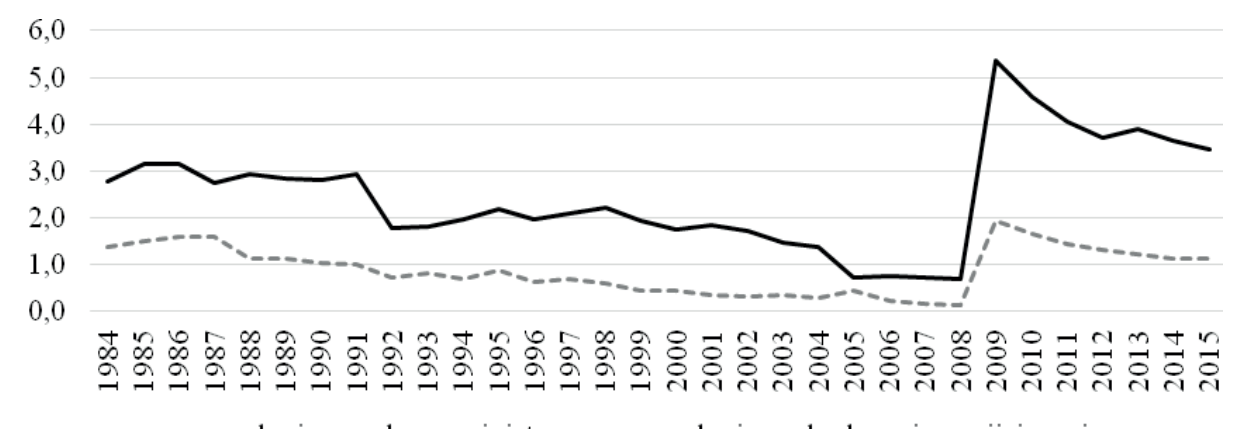

— kraje wysoko rozwiniẹte - ----kraje wschodzạce i rozwijające siẹ

Rysunek 4. Udział SDR w oficjalnych aktywach rezerwowych krajów rozwiniętych oraz wschodzących i rozwijających się (w \%)

Źródło: opracowanie własne na podstawie: lata 1984-1989: IMF, 1990: 66; 1990-1993: IMF, 1996: 162; 1994-1999: IMF, 2000: 110; 2000-2004: IMF, 2005: 108; 2005-2008: IMF, 2010a: 3; 2009-2015 marzec: IMF, 2015: 3

100,0
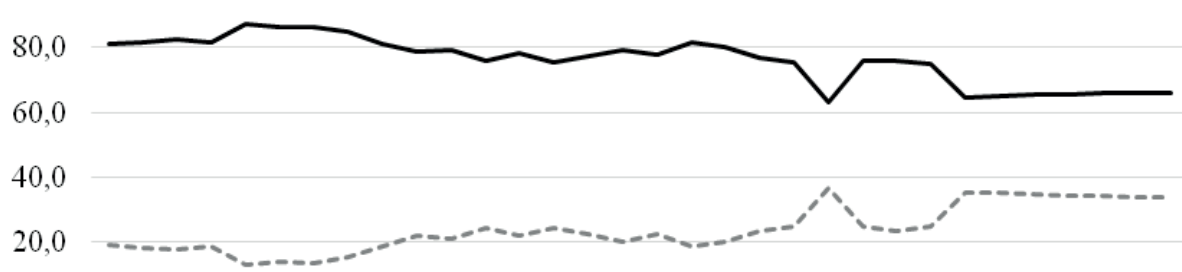

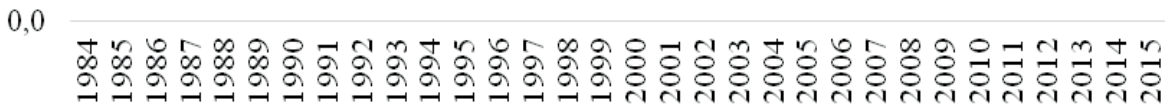
kraje wy soko rozwiniẹte $\quad$-----kraje wschodzace i rozwijajạce siẹ
Rysunek 5. Udział SDR posiadanych przez kraje rozwinięte oraz kraje wschodzące i rozwijające się w całości wyemitowanych SDR (w \%)

Źródło: opracowanie własne na podstawie: lata 1984-1989: IMF, 1990: 66; 1990-1993: IMF, 1996: 162; 1994-1999: IMF, 2000: 110; 2000-2004: IMF, 2005: 108; 2005-2008: IMF, 2010a: 3; 2009-2015 marzec: IMF, 2015: 3

Niski udział krajów rozwijających się w całości zasobów SDR nie jest sytuacją optymalną z punktu widzenia efektywności funkcjonowania międzynarodowego system walutowego, ponieważ to właśnie ta grupa krajów potrzebuje SDR ze względu na utrudniony dostęp do rynków finansowych i konieczność pozyskiwania walut wymienialnych (Skopiec, 2015: 105). 
Tabela 7. Kraje z największym udziałem w alokacji SDR (stan na 1 kwietnia 2017 r.)

\begin{tabular}{|l|c|c|}
\hline \multicolumn{1}{|c|}{ Kraj } & MIn SDR & Udział w całości zasobów SDR (w \%) \\
\hline USA & 82994,2 & 17,46 \\
\hline Japonia & 30820,5 & 6,48 \\
\hline Chiny & 30482,9 & 6,41 \\
\hline Niemcy & 26634,4 & 5,60 \\
\hline Francja & 20155,1 & 4,24 \\
\hline Wielka Brytania & 20155,1 & 4,24 \\
\hline Włochy & 15070,0 & 3,17 \\
\hline Indie & 13114,4 & 2,76 \\
\hline Rosja & 12903,7 & 2,71 \\
\hline Brazylia & 11042,0 & 2,32 \\
\hline \multicolumn{2}{|c|}{ Źródło: opracowanie własne na podstawie: IMF, 2017b }
\end{tabular}

Analizując cechy Specjalnych Praw Ciągnienia jako składników oficjalnych rezerw walutowych, można wskazać zarówno zalety, jak i wady tej jednostki. Pozytywne cechy SDR, które dają im pewną przewagę nad walutami międzynarodowymi i które mogą wpływać na umocnienie się pozycji tych jednostek w strukturze posiadanych rezerw walutowych, to przede wszystkim stabilna wartość wynikająca już z samej konstrukcji koszyka SDR, wiarygodność i bezpieczeństwo oraz niezależność od polityki monetarnej pojedynczego kraju emitującego walutę rezerwową. Jednak słabe strony SDR, takie jak niska płynność, brak szerokiej gamy aktywów nominowanych w tej jednostce, brak rynków SDR i w związku z tym niemożność dokonywania przez banki centralne interwencji walutowych bezpośrednio w SDR, sprawiają, że cały czas ich pozycja jako aktywów rezerwowych jest marginalna.

\section{Bariery w wykorzystaniu SDR}

Oceniając rolę Specjalnych Praw Ciągnienia we współczesnym międzynarodowym systemie walutowym, D.A. Skopiec (2015: 90-91) wymienił dwa główne czynniki ograniczające wykorzystanie SDR jako składnika oficjalnych aktywów rezerwowych i uniemożliwiające przekształcenie SDR w walutę międzynarodową: wewnętrzne i zewnętrzne.

Bariery wewnętrzne polegają na ograniczeniu kreacji SDR oraz wykorzystania tej jednostki w sferze transakcji prywatnych oraz oficjalnych. Wynikają one ze specyfiki i konstrukcji SDR i uwarunkowane są rozwiązaniami przyjętymi w statucie IMF, w więc stanowią ograniczenia prawne. Dotyczą one warunków i sposobu dokonywania emisji SDR oraz uciążliwej procedury alokacji. Stany Zjednoczone, będące głównym udziałowcem funduszu, posiadają tak dużą część głosów, że mogą zablokować przeprowadzenie alokacji SDR. Z kolei kraje rozwi- 
jające się i rynki wschodzące, które są najbardziej zainteresowane zwiększeniem zasobów SDR, nie dysponują wystarczającą pulą głosów, niezbędną do przeprowadzenia nowej alokacji.

Bariery zewnętrzne mają przede wszystkim charakter polityczny i wynikają $\mathrm{z}$ interesów emitentów głównych walut międzynarodowych. Związane są z trendami rozwoju międzynarodowego systemu walutowego, a w szczególności z utrzymującą się rolą dolara amerykańskiego jako dominującej waluty międzynarodowej oraz ze wzrostem międzynarodowego znaczenia renminbi. Ponadto kraje Europy Zachodniej są bardziej zainteresowane promowaniem waluty euro, a wcześniej ECU (Mucha-Leszko, 2013: 107) niż wzmacnianiem pozycji Specjalnych Praw Ciągnienia, dlatego też wykorzystanie SDR jest istotnie ograniczone.

\section{Propozycje reform międzynarodowego systemu walutowego a SDR}

Globalny kryzys finansowo-gospodarczy 2008-2009 wywołał wzrost zainteresowania SDR i rolą tej jednostki w międzynarodowym systemie walutowym. Pojawiły się propozycje reformy międzynarodowego systemu walutowego, w których - jako rozwiązanie problemów wynikających z pełnienia przez waluty narodowe funkcji pieniądza międzynarodowego - postulowano wykorzystanie $\mathrm{w}$ tej roli pieniądza ponadnarodowego kreowanego przez międzynarodową organizację finansową.

W pojawiających się w literaturze koncepcjach modyfikacji międzynarodowego systemu walutowego wyłaniają się dwa główne stanowiska:

1) przejście w kierunku systemu wielodewizowego oraz

2) stworzenie globalnego systemu walutowego przez oparcie go na Specjalnych

Prawach Ciągnienia lub wykreowanie ponadnarodowego pieniądza papierowego (Bogołębska, 2013: 396).

Koncepcje te odwołują się w szczególności do dysfunkcjonalności międzynarodowego systemu walutowego $\mathrm{w}$ zakresie kreacji pieniądza międzynarodowego.

Takie podejście zaprezentował zespół ekonomistów z dwóch europejskich centrów badawczych (Angeloni i wsp., 2011: 36-50), który nakreślił trzy najbardziej prawdopodobne scenariusze zmian w funkcjonowaniu międzynarodowego systemu walutowego. Oprócz scenariusza pierwszego, który zakłada reformę istniejącego systemu walutowego i utrzymanie dominacji dolara, dwa pozostałe scenariusze wiążą się z dość istotnymi zmianami.

Scenariusz drugi wpisuje się w koncepcję stworzenia systemu wielodewizowego z dominacją trzech walut: dolara, euro oraz renminbi, które będą pełniły 
funkcję waluty rezerwowej, zaczepu, a także w sferze transakcji prywatnych. Przewidywane zmiany mają dokonać się przez działanie rynku, jednak niezbędna jest również aktywna polityka gospodarcza Chin i strefy euro. Wzrost umiędzynarodowienia renminbi zależy przede wszystkim od zapewnienia swobody przepływu kapitału, a także od upłynnienia kursu. W przypadku obszaru euro chodzi głównie o poprawę stanu finansów publicznych i równowagi zewnętrznej krajów członkowskich w celu przywrócenia zaufania rynków finansowych do wspólnej waluty. Autorzy nie wykluczają przy tym możliwości, że w przypadku braku działań na rzecz umocnienia międzynarodowej roli euro, podstawą MSW mogą być dwie waluty kluczowe: dolar i renminbi. Ponadto, jeśli nastąpiłby rozwój lokalnych rynków finansowych, waluty lokalne również mogą osiągnąć wyższy stopień umiędzynarodowienia. W praktyce MSW może być bardziej bądź mniej heterogeniczny.

Najbardziej radykalne zmiany opisuje scenariusz trzeci, zakładający powstanie multilateralnego systemu walutowego i nadanie większego znaczenia Specjalnym Prawom Ciągnienia przez ich szerokie zastosowanie w funkcjach fakturowania, zaczepu oraz gromadzenia rezerw. Ta koncepcja jest jednak szczególnie trudna do realizacji, ponieważ wymaga delegowania uprawnień przez kraje do instytucji ponadnarodowej, a - jak wskazują doświadczenia - kraje nie są jeszcze na to gotowe. Nawet inicjatywy grupy G-20, których celem jest wprowadzenie ściślejszej koordynacji polityki walutowej, mają charakter międzyrządowy i nie przewidują delegowania kompetencji do organów ponadnarodowych. Pomysł stworzenia globalnej waluty nie pojawia się po raz pierwszy. Już pod koniec II wojny światowej, kiedy toczyły się debaty nad kształtem nowego międzynarodowego systemu walutowego w Bretton Woods (Mucha-Leszko, 2005: 18), J.M. Keynes zaproponował w 1944 roku utworzenie globalnego pieniądza, który nazwał bancorem. Wydaje się jednak, że model systemu walutowego zaproponowany w scenariuszu trzecim jest możliwy do realizacji, ale bez nadania SDR statusu waluty zewnętrznej, jak chciał tego Keynes dla waluty bancor. Zwiększenie rangi SDR wzmocniłoby multilateralny nadzór nad systemem walutowym sprawowany przez IMF, który miałby łatwiejszy dostęp do finansowania, co sprzyjałoby efektywniejszemu zarządzaniu globalną płynnością finansową. Jak zauważają B. Mucha-Leszko i M. Kąkol (2012: 313-322), multilateralny system walutowy byłby najbardziej dostosowany do przestrzennego wymiaru mechanizmu rynkowego i procesów gospodarczych.

Zbliżoną do scenariusza trzeciego propozycję reformy międzynarodowego systemu walutowego przedstawiono również w ogłoszonym we wrześniu 2009 roku raporcie przygotowanym przez Komisję Ekspertów ONZ ds. Reform Międzynarodowego Systemu Walutowego i Finansowego pod kierownictwem J. Stiglitza (Reform of the Commission..., 2009). Komisja ta uznała, że głównym źródłem niestabilności współczesnego międzynarodowego systemu walutowego są nieefektywne rozwiązania w zakresie kreacji płynności międzynarodowej i zaleciła oparcie tej płynności 
nie na walutach narodowych, lecz na walucie ponadnarodowej. Mogłoby to odbywać się w dwojaki sposób: albo przez wykorzystanie w tym celu SDR, po zwiększeniu podaży tej jednostki oraz jej zastosowania, albo przez emisję nowej waluty ponadnarodowej przez powołaną do tego instytucję - Światowy Bank Rezerw. Komisja ta zaproponowała również zwiększenie częstotliwości i regularności alokacji SDR, uwzględnienie kruszcu w strukturze koszyka walut SDR oraz utworzenie izby rozrachunkowej i systemu clearingowego, co zwiększyłoby płynność oraz przejrzystość rynku, a w konsekwencji również wolumen transakcji z wykorzystaniem SDR.

Również Prezes Ludowego Banku Chin Z. Xiaochuan (2009) ogłosił w marcu 2009 roku propozycję reformy międzynarodowego systemu walutowego, która miałaby polegać na zastąpieniu walut narodowych pieniądzem ponadnarodowym emitowanym przez IMF. Jego zdaniem pieniądz ponadnarodowy zapewniłby bardziej efektywne zaspokajanie popytu na płynność międzynarodową oraz sprzyjałby większej stabilności finansowej w gospodarce światowej.

B. Erten i J.A. Ocampo (2012: 2) twierdzą ponadto, że najbardziej obiecującym sposobem reformy międzynarodowego systemu walutowego w celu zwiększenia jego stabilności, a także wyeliminowania nierównowag, jest pełne wykorzystanie SDR. Autorzy ci argumentują, że:

1) zastąpienie przez SDR walut narodowych w funkcjach pieniądza międzynarodowego mogłoby uwolnić międzynarodowy system walutowy od uzależnienia od polityki pieniężnej wiodącego kraju, który przedkłada interesy krajowe nad skutkami jego decyzji dla systemu międzynarodowego; ponadto renta emisyjna (seigniorage) byłaby dzielona między kraje członkowskie;

2) emisja SDR w sposób antycykliczny i nowe alokacje SDR w czasie kryzysów mogłyby zmniejszać recesyjne oddziaływanie (recessionary bias) związane $\mathrm{z}$ asymetrycznymi korektami krajów nadwyżkowych i deficytowych;

3) dodatkowa alokacja SDR mogłaby zmniejszyć zapotrzebowanie krajów rozwijających się na przezornościową akumulację rezerw; takie rozwiązanie wiązałoby się z niższymi kosztami utrzymywania systemu zabezpieczającego przed kryzysami walutowymi niż gromadzenie rezerw walutowych, akumulowanie nadwyżek na rachunku obrotów bieżących czy zaciąganie pożyczek międzynarodowych.

Jak wskazują powyższe rozważania, wykorzystanie SDR w roli globalnego pieniądza ma wiele zalet, jednak wymagałoby pewnych modyfikacji systemu:

1) zwiększenia podaży SDR przez kolejne alokacje;

2) umożliwienia stosowania SDR w transakcjach handlu międzynarodowego oraz w transakcjach na rynkach finansowych;

3) poszerzenia składu koszyka SDR o waluty największych gospodarek na świecie, w tym krajów rozwijających się;

4) przekazania części rezerw SDR pod zarząd IMF;

5) umożliwienia emisji aktywów denominowanych w SDR. 
Aby więc SDR mogły stać się podstawą MSW, konieczne jest umocnienie ich roli jako waluty międzynarodowej, ponieważ obecnie ich znaczenie jako waluty rezerwowej, międzynarodowej jednostki rozrachunkowej oraz występowanie w innych funkcjach jest niewielkie (ilość SDR nigdy nie przekroczyła 6\% wszystkich rezerw światowych). W tym kontekście pojawiają się liczne propozycje zmian w ich działaniu. Poszerzenie roli SDR w międzynarodowym systemie walutowym postulują między innymi Chiny, które upatrują w nich szansę na zakończenie dominacji dolara amerykańskiego. Równocześnie, od wybuchu globalnego kryzysu 2008-2009, Chiny dążą do umiędzynarodowienia swojej waluty renminbi, czego efektem było jej włączenie do koszyka SDR w październiku 2016 roku.

Jak zauważa B. Eichengreen (2009: 61-62), przejęcie przez SDR funkcji waluty międzynarodowej jest możliwe, jednak wymaga rozszerzenia koszyka walut, zwiększenia rezerw walutowych w SDR, uelastycznienia emisji SDR, stworzenia dla nich płynnego rynku, na którym rządy państw oraz prywatne korporacje mogłyby emitować obligacje nominowane w SDR.

Niektórzy ekonomiści uważają z kolei, że reformy polegające na oparciu MSW na SDR są niewłaściwe, ponieważ znaczne zwiększenie roli SDR zależy od ich przekształcenia w aktywa utrzymywane przez sektor prywatny (Cooper, 2009; Eichengreen, 2009; Padoa-Schioppa, 2011). Jednak oprócz faktu, że spowodowałoby to potrzebę głębokiej reformy systemu, problemem może być również pojawienie się spekulacyjnego popytu na globalną walutę rezerwową. Ponadto wprowadzenie reformy uniemożliwiać może sprzeciw Stanów Zjednoczonych. Z tego względu bardziej prawdopodobna wydaje się reforma polegająca na zwiększeniu wykorzystania SDR w sferze oficjalnej i kontynuowaniu stosowania walut narodowych lub regionalnych w prywatnych transakcjach.

\section{Podsumowanie}

Na obecnym etapie funkcjonowania międzynarodowego systemu walutowego, biorąc pod uwagę definicję oraz funkcje waluty międzynarodowej, trudno jest uznać SDR za pieniądz międzynarodowy, ponieważ jednostka ta nie pełni żadnej funkcji waluty międzynarodowej w sferze prywatnej, a w sferze oficjalnej pełni jedynie funkcję waluty rezerwowej, jednak w bardzo ograniczonym zakresie.

Jedną z przyczyn takiego stanu rzeczy są formalne bariery wykorzystania Specjalnych Praw Ciągnienia, głównie w sferze transakcji prywatnych, co skutecznie zmniejsza atrakcyjność SDR jako jednostki pełniącej poszczególne funkcje waluty międzynarodowej w sferze oficjalnej, gdyż wszystkie te funkcje są od siebie zależne.

Zwiększenie wykorzystania SDR w pełnieniu funkcji pieniądza międzynarodowego jest uwarunkowane dwoma czynnikami: 
1) zmianą polityki i nastawienia największych gospodarek oraz

2) eliminacją ograniczeń prawnych wykorzystania SDR w sferze transakcji prywatnych.

Oparcie MSW na SDR mogłoby przynieść korzyści z punktu widzenia stabilności systemu, między innymi wynikające z:

1) mniejszej zmienności wartości waluty koszykowej w porównaniu do indywidualnych walut,

2) braku uzależnienia od sytuacji gospodarczej w jednym kraju (oddziaływania polityki pieniężnej prowadzonej przez bank centralny USA na sytuację walutową na świecie),

3) antycyklicznej emisji SDR w czasie kryzysów oraz

4) zmniejszenia kosztów akumulacji rezerw walutowych.

Wymienione wyżej argumenty uzasadniają postawioną we wstępie hipotezę mówiącą, że wzrost roli SDR w pełnieniu funkcji waluty międzynarodowej umożliwiłby reformę międzynarodowego systemu walutowego zwiększającą jego stabilność. Pojawiają się jednak liczne pytania i wątpliwości związane z transformacją SDR w walutę globalną, gdyż proces ten wymagał będzie rozwoju rynku prywatnego SDR. Poza tym aktualna konstrukcja SDR sprawia, że nie są one skutecznym instrumentem kreacji płynności, a jedynie transferują globalną płynność między krajem mającym nadwyżki i odczuwającym brak płynności.

Zaprezentowane koncepcje reform międzynarodowego systemu walutowego, które powstały głównie w czasie globalnego kryzysu finansowo-gospodarczego, przypisują duże znaczenie wzrostowi roli SDR. Jednak po wyjściu z głębokiej fazy kryzysu zainteresowanie SDR ponownie spadło. Może to świadczyć o tym, że możliwości realnego zwiększenia roli SDR są niewielkie, a przedstawiane propozycje w warunkach względnego ustabilizowania międzynarodowego systemu walutowego mają niewielkie szanse na realizację. W obecnych warunkach bardziej prawdopodobna wydaje się koordynacja polityki walutowej głównych gospodarek (Twarowska, 2016b: 661).

\section{Bibliografia}

Aiyar S. (2009), An International Monetary Fund Currency to Rival the Dollar? Why Special Drawing Rights Can't Play That Role, „Center for Global Liberty and Prosperity. Development Policy Analysis", nr 10, s. 1-14.

Aizenman J., Lee J. (2006), Financial Versus Monetary Mercantilism: Long-term View of Large International Reserve Hoarding, IMF Working Paper, t. 280.

Angeloni I., Bénassy-Quéré A., Carton B., Darvas Z., Destais Ch., Pisani-Ferry J., Sapir A., Vallee S. (2011), Global currencies for tomorrow: a European perspective, „European Economy", nr 444, s. 1-99.

Bilski J. (2006), Międzynarodowy system walutowy, Polskie Wydawnictwo Ekonomiczne, Warszawa. 
Bilski J. (2015), Pieniadz międzynarodowy w powojennej historii międzynarodowego systemu walutowego. Teoria i praktyka, „Acta Universitatis Lodziensis. Folia Oeconomica”, nr 5(316), s. $5-25$.

Bird G. (2003), The IMF and the Future. Issues and options facing the Fund, Routledge, London. Bloomberg (2015), China Communist Party Proposes Yuan Convertibility by 2020, www.bloomberg.com [dostęp: 1.04.2017].

Bogołębska J. (2011), Popyt na rezerwy walutowe - ewolucja koncepcji teoretycznych a wspótczesne doświadczenia gospodarki światowej, „Acta Universitatis Lodziensis. Folia Oeconomica", nr 260, s. 49-60.

Bogołębska J. (2013), Nierównowagi globalne a stabilność międzynarodowego systemu walutowego. Analiza na przyktadzie akumulacji rezerw walutowych, Wydawnictwo Uniwersytetu Łódzkiego, Łódź.

Boughton J.M. (2001), Silent revolution: the International Monetary Fund, 1979-1989, IMF, Washington.

Clark P., Polak J. (2004), International Liquidity and the Role of the SDR in the International Monetary System, IMF Staff Papers, t. 51, nr 1.

Cooper R.N. (2009), The future of the dollar, „Policy Briefs in International Economics”, Peterson Institute for International Economics, Washington.

COFER (2017), Currency Composition of Official Foreign Exchange Reserves, International Monetary Fund, https://data.world/imf/currency-composition-of-offici [dostęp: 19.02.2017].

Eichengreen B. (2009), The Dollar Dilemma: The World's Currency Faces Competition, „Foreign Affairs", t. 88, nr 5, s. 53-68.

Eichengreen B., Frankel J.A. (1996), On the SDR: Reserve Currencies and the Future of the International Monetary System, Center for International and Development Economics Research (CIDER) Working Papers, No C96-068, University of California, Berkeley.

Erten B., Ocampo J.A. (2012), Building a stable and equitable global monetary system, „Economic \& Social Affairs”, DESA Working Paper nr 118, ST/ESA/2012/DWP/118, August.

IMF (1990), IMF Annual Report 1990. Appendix I, Washington.

IMF (1996), IMF Annual Report 1996. Appendix I, Washington.

IMF (2000), IMF Annual Report 2000. Appendix I, Washington.

IMF (2005), IMF Annual Report 2005. Appendix I, Washington.

IMF (2010a), IMF Annual Report 2010. Appendix I, Washington.

IMF (2010b), Review of the Method of Valuation of the SDR, October 26, Washington.

IMF (2015), IMF Annual Report 2015. Appendix I, Washington.

IMF (2016), IMF Annual Report 2016, Washington.

IMF (2017a), World Economic Outlook Database October 2016, www.imf.org [dostęp: 19.02.2017].

IMF (2017b), IMF Members' Quotas and Voting Power, and IMF Board of Governors, www.imf. org [dostęp: 1.04.2017].

Jurek M. (2011), Międzynarodowy system walutowy i systemy kursowe w warunkach integracji finansowej, Wydawnictwo Uniwersytetu Ekonomicznego w Poznaniu, Poznań.

Kenen P.B. (1983), The role of the dollar as an international currency, Occasional Papers 13, Group of Thirty, New York.

Liberska B. (2010), Perspektywy rozwojowe chińskiej gospodarki do 2010 roku, „Studia Ekonomiczne", nr 4, s. 331-358.

Mucha-Leszko B. (2005), Rozwój powiązań w gospodarce światowej-etapy globalizacji i regionalizacja procesów gospodarczych, [w:] B. Mucha-Leszko (red.), Wspótczesna gospodarka światowa. Główne centra gospodarcze, Wydawnictwo Uniwersytetu Marii Curie-Skłodowskiej, Lublin.

Mucha-Leszko B. (2013), Hiszpania w unii walutowej, „Annales UMCS. Sectio H Oeconomia”, t. 47 , nr 1, s. 107-120. 
Mucha-Leszko B., Kąkol M. (2012), Globalizacja i zmiany w układzie sił gospodarczych a międzynarodowy system walutowy, [w:] E. Molendowski (red.), Globalizacja i regionalizacja we wspótczesnym świecie, Wydawnictwo Uniwersytetu Ekonomicznego w Krakowie, Kraków.

Mucha-Leszko B., Twarowska K. (2016), Czynniki i skutki destabilizacji kursów walutowych po upadku systemu walutowego z Bretton Woods, „Studia Ekonomiczne. Zeszyty Naukowe Uniwersytetu Ekonomicznego w Katowicach", nr 266, s. 49-60.

Nakonieczna-Kisiel H. (2013), Rezerwy walutowe we wspótczesnej gospodarce światowej, „Studia i Prace Wydziału Nauk Ekonomicznych i Zarządzania”, nr 33, s. 93-109.

Neely Ch.J. (2017), Chinese Foreign Exchange Reserves, Policy Choices and the U.S. Economy, Working Paper Series 2017-001A, Federal Reserve Bank of St. Louis, files.stlouisfed.org [dostęp: 28.03.2017].

Obstfeld M. (2011), The SDR as an International Reserve Asset: What Future?, Paper nr 11/0885, International Growth Centre, London.

Padoa-Schioppa T. (2011), The ghost of bancor: The economic crisis and global monetary disorder, [w:] J.T. Boorman, A. Icard (eds.), Reform of the International Monetary System, chapter 6, SAGE Publications, The Palais Royal Initiative, New Delhi.

Proczek M. (2016), Stara - nowa rola SDR w międzynarodowym systemie walutowym, „Kwartalnik Naukowy Uczelni Vistula", nr 1(47), s. 119-132.

Reform of the Commission of Experts of the President of the United Nations General Assembly on Reforms of the International Monetary and Financial System (2009), United Nations, New York.

Schroder J. (1990), The Role of the SDRs in the International Monetary System, [w:] E.-M. Claassen (ed.), International and European Monetary Systems, Praeger, New York.

Skopiec D.A. (2015), Rola specjalnych praw ciagnienia we wspótczesnym międzynarodowym systemie walutowym, „Gospodarka Narodowa”, $\mathrm{nr}$ 5, s. 89-118.

Smaghi L.B. (2011), The Triffin dilemma revisited, Speech by Mr Lorenzo Bini Smaghi, Member of the Executive Board of the European Central Bank, at the Conference on the International Monetary System: sustainability and reform proposals, marking the 100th anniversary of Robert Triffin (1911-1993), at the Triffin International Foundation, Brussels, 3 October 2011, www.bis.org [dostep: 1.04.2017].

Stooq (2017), Serwis finansowy Stooq, https://stooq.pl/ [dostęp: 1.04.2017].

Twarowska K. (2016a), Ocena pozycji walut kluczowych międzynarodowego systemu walutowego w latach 1990-2016 i perspektywy zmian, referat zaprezentowany na konferencji „Aktualne tendencje w międzynarodowych stosunkach gospodarczych", SGGW, Kociszew.

Twarowska K. (2016b), Efekty międzynarodowej koordynacji polityki walutowej w latach 1978-2015, „Prace Naukowe Uniwersytetu Ekonomicznego we Wrocławiu”, nr 4, s. 652-664.

UNCTAD (2017), Baza danych UNCTADStat, unctadstat.unctad.org [dostęp: 1.04.2017].

Wilkie C. (2012), Special Drawing Rights. The First International Money, Oxford University Press, New York.

Xiaochuan Z. (2009), Reform the International Monetary System, „Bank for International Settlements. Review", nr 41, s. 1-3. 


\title{
The Role of the SDR with the Prospect of Changes in the Functioning of the International Monetary System
}

\begin{abstract}
The discussion on the need to improve the efficiency of the international monetary system generates many proposals for its reform. In the literature there are two main standpoints on the modification of the international monetary system: 1) the transition to a multi-currency system and 2) the formation of a global monetary system based on SDRs or the creation of transnational paper money. These circumstances are a precondition for research, which aims to analyze the use of SDRs in the functions of international currency and to assess the possibility of an international monetary system reform based on an increased role for SDRs. The carried out studies show that the SDRs have ability to perform the international currency functions, but it requires significant changes in policies of the state and the creation of conditions for wider use of SDRs, both in the area of official and private transactions. The author uses research methods including a study of literature on the subject and an analysis of statistical data, mainly IMF and UNCTAD.
\end{abstract}

Keywords: SDR, international monetary system, international currency, foreign exchange reserves, international liquidity

JEL: F02, F31, F41, G15

\begin{tabular}{|l|l|}
\hline \multirow{2}{*}{ OPEN ACCESS } & $\begin{array}{l}\text { @ by the author, licensee Łódź University - Łódź University Press, Łódź, Poland. } \\
\text { This article is an open access article distributed under the terms and conditions } \\
\text { of the Creative Commons Attribution license CC-BY } \\
\text { (http: //creativecommons.org/licenses/by/3.0/) }\end{array}$ \\
\cline { 2 - 2 } & Received: 2017-06-25; verified: 2017-09-24. Accepted: 2018-02-28 \\
\hline
\end{tabular}

